\title{
DINUCLEAR COPPER(II) ACETATE COMPLEX WITH CAFFEINE, A FAST MECHANOCHEMICAL SYNTHESIS
}

\author{
Marina Tašner, Draginja Mrvoš-Sermek*, Emina Hajdarpašić, Dubravka Matković-Čalogović \\ Department of Chemistry, Faculty of Science, University of Zagreb, Croatia \\ *e-mail: mrvos@chem.pmf.hr
}

\begin{abstract}
A new dinuclear paddle-wheel copper(II) complex with caffeine was synthesized by the solvent-based and mechanochemical methods from copper(II) acetate and caffeine in a 1:1 molar ratio. Mechanochemical synthesis was found to be the fastest and easiest way to prepare the complex. The reaction proceeds with addition of small amounts of methanol or ethanol. The complex was characterized by FT-IR spectroscopy, elemental and thermoanalytical methods (TG and DSC) and X-ray diffraction methods. The molecular and crystal structure was determined by the single crystal $\mathrm{X}$-ray diffraction method. The complex molecule consists of a centrosymmetric dinuclear unit, $\left[\mathrm{Cu}_{2}(\mu \text {-Ac })_{4}(\mathrm{caf})_{2}\right]$, with two copper(II) atoms bridged by four acetato groups, and $N$-coordinated caffeine (caf) molecules in the apical positions.
\end{abstract}

Key words: copper(II); paddle-wheel structure; caffeine; crystal structure; mechanochemical synthesis

\section{INTRODUCTION}

Caffeine (3,7-dihydro-1,3,7-trimethyl-1H-purine-2,6-dione) is a purine alkaloid with very interesting pharmacological properties as a therapeutic agent with analeptic activity. The coordination chemistry of the purine type ligands has been subjected to intensive studies because of the importance of the interaction between these ligands and metal ions in many biological systems $[1,2]$.

A few crystal structures of copper(II) compounds with caffeine (caf) in which the copper(II) atoms are five coordinated have been described. Two monomeric examples are triaqua(caf)nitratocopper(II) nitrite [3] and aqua(caf)dichlorocopper(II) [4]. Caffeine usually prefers the nitrogen atom as the donor atom, especially in the copper(II) carboxylate complexes [5-14] (see Table 1). In $\left.\left[\mathrm{Cu}_{2} \text { (flufenamato }\right)_{4}(\mathrm{caf})\left(\mathrm{H}_{2} \mathrm{O}\right)\right]$ [15] two copper(II) atoms are bridged by four carboxylato groups, but one apical ligand is a caffeine molecule and the other one is a water molecule. The only example in the series of dimeric copper(II) carboxylates where both apical position are occupied by $O$-coordinated caffeine molecules is $\left[\mathrm{Cu}_{2}(3,5 \text {-dinitrobenzoato })_{4}(\mathrm{caf})_{2}\right]$ [16]. The authors comment that the possible reason why this caffeine complex does not contain metal- $\mathrm{N}$ bonding is a steric effect caused by the size of the 3,5-dinitrobenzoato ligand.

In general, copper(II) carboxylates can contain a mononuclear, dinuclear or polynuclear structural unit. Scheme 1 shows some of the most frequently encountered coordination modes of carboxylate ligands in metal complexes.

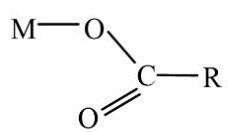

a

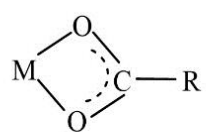

b

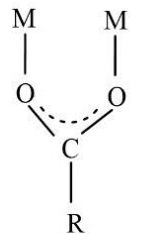

c
Scheme 1. Carboxylate coordination modes: (a) monodentate; (b) chelate; (c) bidentate bridging 
All of the dinuclear $\left[\mathrm{Cu}_{2}(\mathrm{RCOO})_{4} \mathrm{XY}\right]$ complexes, $\left(\mathrm{RCOO}^{-}=\right.$carboxylate; $\mathrm{X}, \mathrm{Y}=$ usually $N$ - or $O$-donor ligands), have the paddle-wheel cage structure, as shown in Figure 1, in which each of the four carboxylate ligands is bound to both copper(II) ions in a bridging bidentate fashion. Each copper atom is coordinated by four oxygen atoms from the carboxylate ligands in the equatorial plane and can further accommodate a monodentate ligand, such as caffeine, in the apical position.

Some geometric parameters in the dinuclear complexes of the $\left[\mathrm{Cu}_{2}(\mathrm{RCOO})_{4}(\mathrm{caf})_{2}\right]$ type, with caffeine as a $\mathrm{N}$ - or $\mathrm{O}$-donor are presented in Table 1. In the Cambridge Structural Database (CSD) [17], Version 1.2.1 (2018), there are 12 such crystal structures. There is a relationship between the $\mathrm{Cu} \cdots \mathrm{Cu}$ distances and the distance of the copper(II) atom from the $4 \mathrm{O}$ equatorial basal plane towards the apical caffeine ligand, as the former is elongated the latter also increases. However, there is no relationship with the $\mathrm{Cu}-\mathrm{N}$ bond length. The observed differences in the geometry of the paddle-wheel unit can be attributed to the influence of different $\mathrm{RCOO}^{-}$ligands.

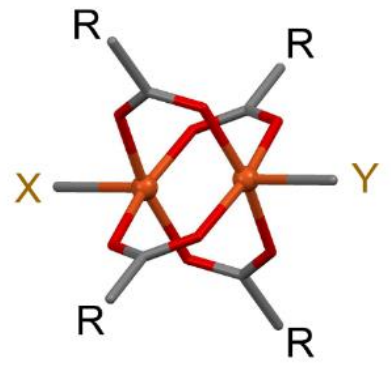

Figure 1. Drawing of a paddle-wheel unit. $\mathrm{RCOO}^{-}=$carboxylate, $\mathrm{X}$ and $\mathrm{Y}$ are usually $\mathrm{N}$ - or $\mathrm{O}$-donor ligands. Copper atoms are shown as spheres.

Table 1. Summary data of the $\left[\mathrm{Cu}_{2}(\mathrm{RCOO})_{4}(\mathrm{caf})_{2}\right]$ complexes

\begin{tabular}{|c|c|c|c|c|c|}
\hline $\begin{array}{l}\text { Refcode*/Formula or name } \\
\text { of } \mathrm{RCOO}^{-}\end{array}$ & $\begin{array}{c}d(\mathrm{Cu} \cdots \mathrm{Cu}) / \\
\AA\end{array}$ & $\begin{array}{c}d\left(\mathrm{Cu}-\mathrm{O}_{\mathrm{eq}}\right)(\mathrm{av})^{* * /} \\
\AA\end{array}$ & $\begin{array}{c}d\left(\mathrm{Cu}-\mathrm{N}_{\mathrm{ap}}\right) / \\
\AA\end{array}$ & $\begin{array}{c}\mathrm{Cu}-4 \mathrm{O}_{\text {eq }} \text { plane } \\
/ \AA\end{array}$ & Ref. \\
\hline $\begin{array}{l}\text { KUBJUM } \\
\mathrm{C}_{6} \mathrm{H}_{5} \mathrm{COO}^{-}\end{array}$ & $2.647(1)$ & $1.967(2,11)$ & $2.222(3)$ & 0.204 & [5] \\
\hline $\begin{array}{l}\text { XIRCOQ } \\
(2 S)-2-(6-m e t h o x y- \\
\text { naphthalen-2-yl)propionato }\end{array}$ & $2.649(1)$ & $1.963(5,16)$ & $2.226(4)$ & 0.216 & [6] \\
\hline $\begin{array}{l}\text { QOPHOT } \\
\mathrm{CH}_{3} \mathrm{CH}(\mathrm{Br}) \mathrm{COO}^{-} \\
\text {(monoclinic form) }\end{array}$ & $2.6735(8)$ & $1.943(4,2)$ & $2.183(5)$ & 0.222 & {$[7]$} \\
\hline $\begin{array}{l}\text { KIGMOD } \\
\text { 2-[(2-Hydroxy- } \\
\text { benzoyl)oxy]benzoato }\end{array}$ & $2.680(1)$ & $1.968(4,15)$ & $2.168(5)$ & 0.219 & {$[8]$} \\
\hline $\begin{array}{l}\mathrm{REPVEO} \mathrm{/} \mathrm{CH}_{3} \mathrm{CH}(\mathrm{Br}) \mathrm{COO}^{-} \\
\text {(triclinic form) }\end{array}$ & 2.694(1) & $1.966(5,13)$ & $2.231(7)$ & 0.221 & [9] \\
\hline $\begin{array}{l}\text { QOXLAQ } \\
\text { 2-Iodobenzoato }\end{array}$ & $2.7041(6)$ & $1.966(2,8)$ & $2.238(2)$ & 0.236 & [10] \\
\hline DAJVAL/ $\mathrm{CH}_{2} \mathrm{ClCOO}^{-}$ & $2.711(3)$ & $1.98(4,1)$ & $2.23(4)$ & 0.236 & [11] \\
\hline $\begin{array}{l}\text { RERVAL } \\
\mathrm{C}_{6} \mathrm{H}_{5} \mathrm{C}(\mathrm{O}) \mathrm{COO}^{-}\end{array}$ & $2.745(1)$ & $1.975(4,5)$ & $2.161(5)$ & 0.259 & {$[12]$} \\
\hline $\begin{array}{l}\text { FOZKOM / } \mathrm{CCl}_{3} \mathrm{COO}^{-} \text {(ben- } \\
\text { zene solvate) }\end{array}$ & $2.852(2)$ & $1.973(4,17)$ & $2.121(5)$ & 0.315 & [13] \\
\hline \multirow[t]{2}{*}{$\mathrm{KUHFUO} / \mathrm{CCl}_{3} \mathrm{COO}^{-}$} & $3.062(2)$ & $2.011(2,16)$ & $2.0458(2)$ & 0.415 & [14] \\
\hline & & \multicolumn{4}{|c|}{$d\left(\mathrm{Cu}-\mathrm{O}_{\mathrm{ap}}\right) / \AA$} \\
\hline \multirow[t]{2}{*}{$\begin{array}{l}\text { KELXEF } \\
\text { 3,5-dinitrobenzoato }\end{array}$} & 2.661(3) & $1.958(2,25)$ & $2.180(3)$ & 0.200 & [16] \\
\hline & & & $\begin{array}{l}d\left(\mathrm{Cu}-\mathrm{O}_{\mathrm{ap}}\right) / \AA \\
d\left(\mathrm{Cu}-\mathrm{N}_{\mathrm{ap}}\right) / \AA\end{array}$ & & \\
\hline KUHGUP*** / $\mathrm{CCl}_{3} \mathrm{COO}^{-}$ & $2.7364(9)$ & $1.956(7,12)$ & $\begin{array}{l}2.112(4) \\
2.115(4)\end{array}$ & 0.241 & [14] \\
\hline
\end{tabular}

* in CSD

** the first number in parentheses is the e.s.d. and the second is the maximum deviation from the mean value $* * *$ polymeric 
Mechanochemical synthesis by neat grinding (NG) or liquid-assisted grinding (LAG), either done by using agate mortar and pestle or by ball-milling, is now a widely used method for synthesis without solvent or with just a small amount of a solvent. This is especially important in "green chemistry" by avoiding large amounts of organic solvents. In a review by Friščić and co-workers [18] syntheses by the NG or LAG methods resulting in different coordination polymers, metal-organic frameworks (MOFs) and metallodrugs have been discussed. They have shown that the reaction of copper(II) oxide with acetic acid by the LAG (water) method proceeded via an intermediate solvate of acetic acid with copper(II) acetate hydrate, which subsequently transformed into the final product copper(II) acetate hydrate [19]. Copper(II) acetate hydrate was also used in the first solvent-free synthesis of a porous MOF in a ball-milling reaction with isonicotinic acid. Technologically important porous framework HKUST-1, $\quad\left[\mathrm{Cu}_{3}(\mathrm{btc})_{2}, \quad\right.$ btc $=1,3,5$-benzenetricarboxylate], was obtained by grinding copper(II) acetate with 1,3,5-benzenetricarboxylic acid. $\mathrm{In}_{\mathrm{Cu}_{3}(\mathrm{btc})_{2}}$ a pair of $\mathrm{Cu}^{2+}$ ions is chelated by four carboxylate bridges forming a paddle-wheel moiety. 1,3,5benzenetricarboxylate is a linker molecule to three neighboring pairs of copper ions forming thus a 3D network [20, 21].

As a part of our interest in copper(II) complexes with molecules of biological importance [22, 23] we describe the synthesis and crystal structure of a new dinuclear copper complex tetrakis $(\mu$ acetato-O:O')-bis(1,3,7-trimethylpurine-2,6-dione) dicopper(II), $\left[\mathrm{Cu}_{2}(\mu-\mathrm{Ac})_{4}(\mathrm{caf})_{2}\right], \mathrm{Ac}=\mathrm{CH}_{3} \mathrm{COO}^{-}$.

\section{EXPERIMENTAL}

\section{General considerations}

Chemicals were obtained from Sigma-Aldrich and used without previous purification. Elemental C, H, N analysis: Perkin-Elmer 2400 Series II CHNS analyzer in the Analytical Services Laboratories of the Ruđer Bošković Institute, Zagreb, Croatia. FT-IR spectra (KBr pellets): PerkinElmer Spectrum Two. TG and DTA curves were obtained by using Mettler-Toledo TGA/SDTA 851e module. The samples of about 2 to $5 \mathrm{mg}$ were placed in alu- minium pans $(40 \mu \mathrm{l})$. The TGA and DTA curves were obtained with a heating rate of $10{ }^{\circ} \mathrm{C} \mathrm{min}{ }^{-1}$ under a oxygen flow of $200 \mathrm{ml} \mathrm{min}{ }^{-1}$. The samples were heated from room temperature up to $600{ }^{\circ} \mathrm{C}$. DSC measurements were performed on a MettlerToledo DSC $823^{\mathrm{e}}$ module in aluminium pans $(40 \mu \mathrm{l})$, heated in oxygen $\left(200 \mathrm{ml} \mathrm{min}{ }^{-1}\right)$ at a rate of $10{ }^{\circ} \mathrm{C}$ $\mathrm{min}^{-1}$. The samples were heated from room temperature up to $500{ }^{\circ} \mathrm{C}$. The data collection and analysis was performed using the program package STARe Software 9.01 [24]. A Retch MM200 grinder operating at $25 \mathrm{~Hz}$ frequency and teflon jars (14 $\mathrm{ml}$ in volume; using stainless steel grinding ball of 8 $\mathrm{mm}$ in diameter) were used for the grinding experiment.

\section{Single-crystal X-ray diffraction}

The single crystal $\mathrm{X}$-ray diffraction data were collected at $293 \mathrm{~K}$ on an Oxford Diffraction Xcalibur $3 \mathrm{CCD}$ diffractometer with graphite-monochromated $\mathrm{MoK}_{\alpha}$ radiation $(\lambda=0.71073 \AA)$. The data were reduced using CrysAlisPRO software package [25]. The solution, refinement, and analysis of the structure was done using the software integrated in the WinGX system [26]. The structure was solved by the Patterson method using SHELXS [27] and refined by the full-matrix least-squares method based on $F^{2}$ against all data (SHELXL) [28]. All non-hydrogen atoms were refined anisotropically. The hydrogen atoms were introduced in calculated positions and refined using the appropriate riding model. Geometrical calculations were made using PLATON [29] and molecular graphics were prepared using Mercury [30], ORTEP-3 [31] and POVRay [32]. The main crystallographic data with refinement details are summarized in Table 2.

\section{Powder X-ray diffraction}

Powder X-ray diffraction (PXRD) data were collected on a PANalytical Aeris diffractometer in the Bragg-Brentano geometry using $\mathrm{CuK}_{\alpha}$ radiation. The sample was contained on a zero background $\mathrm{Si}$ plate. Patterns were collected in the scan range of $2 \theta$ $=5-50^{\circ}$ with the step size of $0.0027^{\circ}$ and at 9 s per step. The data were visualized using the HighScore Plus program [33]. 
Table 2. Crystal data and details of crystal structure refinement

\begin{tabular}{|c|c|}
\hline Compound & {$\left[\mathrm{Cu}_{2}(\mu-\mathrm{Ac})_{4}(\mathbf{c a f})_{2}\right]$} \\
\hline Formula & $\mathrm{C}_{24} \mathrm{H}_{32} \mathrm{Cu}_{2} \mathrm{~N}_{8} \mathrm{O}_{12}$ \\
\hline $\begin{array}{l}M_{\mathrm{r}} \\
\text { Habit and colour }\end{array}$ & $\begin{array}{l}751.66 \\
\text { prism, dark blue-green }\end{array}$ \\
\hline Crystal dimension $/ \mathrm{mm}^{3}$ & $0.18 \times 0.21 \times 0.39$ \\
\hline Crystal system, space group & triclinic, $\mathrm{P}-1$ \\
\hline$a / \AA$ & $7.9252(2)$ \\
\hline$b / \AA$ & $9.1257(3)$ \\
\hline$c / \AA$ & $11.2138(3)$ \\
\hline$\alpha /^{\circ}$ & 103.931(3) \\
\hline$\beta /^{\circ}$ & $100.629(2)$ \\
\hline$\gamma /{ }^{\circ}$ & $99.372(3)$ \\
\hline $\mathrm{V} / \AA^{3}$ & $755.17(4)$ \\
\hline $\mathrm{Z}$ & 1 \\
\hline$D_{\mathrm{c}} / \mathrm{g} \mathrm{cm}^{-3}$ & 1.653 \\
\hline$\mu / \mathrm{mm}^{-1}$ & 1.483 \\
\hline$F(000)$ & 386 \\
\hline$\Theta$ range for data collection $/{ }^{\circ}$ & $4.147-29.497$ \\
\hline$h, k, l$ range & $-10: 10 ;-12: 12 ;-15: 15$ \\
\hline No. of measured reflections & 21467 \\
\hline No. independent reflections $\left(R_{\text {int }}\right)$ & 4187 \\
\hline No. observed reflections, $I \geq 2 \sigma(I)$ & 3889 \\
\hline$R^{\mathrm{a}}, w R^{\mathrm{b}}[I \geq 2 \sigma(I)]$ & 0.0228 \\
\hline$R, w R$ [all data] & 0.0253 \\
\hline Goodness of fit on $F^{2}, S^{\mathrm{c}}$ & 1.033 \\
\hline Max., min. electron density / e $\AA^{-3}$ & $0.312,-0.208$ \\
\hline 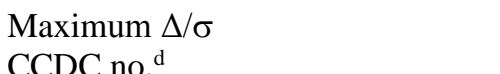 & $\begin{array}{l}0.001 \\
1873412\end{array}$ \\
\hline
\end{tabular}

(a) $R=\Sigma|| F_{\mathrm{o}}|-| F_{\mathrm{c}}|/ \Sigma| F_{\mathrm{o}} \mid$

(b) $w R=\left[\Sigma\left(F_{\mathrm{o}}{ }^{2}-F_{\mathrm{c}}{ }^{2}\right)^{2} / \Sigma w\left(F_{\mathrm{o}}{ }^{2}\right)^{2}\right]^{1 / 2}$

(c) $S=\Sigma\left[w\left(F_{\mathrm{o}}^{2}-F_{\mathrm{c}}^{2}\right)^{2} /\left(N_{\mathrm{obs}}-N_{\mathrm{param}}\right)\right]^{1 / 2}$

(d) CCDC number contains the supplementary crystallographic data for this paper.

These data are provided free of charge by the Cambridge Crystallographic Data Centre.

\section{Synthesis of $\left[\mathrm{Cu}_{2}(\mu-\mathrm{Ac})_{4}(\mathrm{caf})_{2}\right]$}

Mechanochemical synthesis: the liquidassisted grinding method was used. Copper(II) acetate monohydrate $(0.199 \mathrm{~g}, 1 \mathrm{mmol})$ and caffeine $(0.194 \mathrm{~g}, 1 \mathrm{mmol})$ were weighed into a teflon jar, and 2 drops of methanol or ethanol were added. Milling was performed at room temperature for 1 hour.

Slurry method: neat grinding was performed by grinding copper(II) acetate $(0.199 \mathrm{~g}, 1 \mathrm{mmol})$ and caffeine $(0.194 \mathrm{~g}, 1 \mathrm{mmol})$ with a mortar and pestle for $15 \mathrm{~min}$. A homogenized mixture of copper(II) acetate monohydrate and caffeine is obtained in this way (Fig. 2a, left). If two drops of methanol are ad- ded while grinding (LAG/MeOH) the powder is still only the mixture of reactants. The powder was then mixed with a few drops of methanol or ethanol in an Eppendorf tube to form a slurry. A change in color from cyan to dark blue-green occurs very fast. The reaction is completed in minutes (Figure 2a, right).

Solution-based synthesis: a solution of caffeine $(0.194 \mathrm{~g}, 1 \mathrm{mmol})$ in $15 \mathrm{ml}$ methanol (or ethanol) was added to a solution of copper(II) acetate monohydrate $(0.199 \mathrm{~g}, 1 \mathrm{mmol})$ in $12 \mathrm{ml}$ methanol. The mixture was heated to $60^{\circ}$ and refluxed for 1 hour and then left to cool at room temperature. 


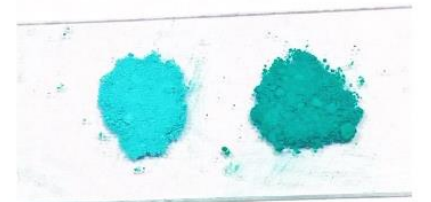

a

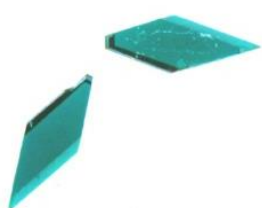

b
Figure 2. a) Powder on the left (light blue-green; cyan) was obtained after NG or LAG (mortar and pestle) for $15 \mathrm{~min}$. It is a mixture of copper(II) acetate monohydrate and caffeine.

Powder on the right is that of $\left[\mathrm{Cu}_{2}(\mu \text {-Ac })_{4}(\mathrm{caf})_{2}\right]$, obtained after addition of methanol or ethanol to the NG/LAG powder to form a slurry. It is of dark blue-green color.

b) Single crystals of $\left[\mathrm{Cu}_{2}(\mu \text {-Ac })_{4}(\mathrm{caf})_{2}\right]$ obtained by the solution-based synthesis.

Dark blue-green crystals were isolated by filtration, washed several times with cold ethanol and dried in air (Figure 2b). Anal. $\mathrm{C}_{24} \mathrm{H}_{32} \mathrm{~N}_{8} \mathrm{O}_{12} \mathrm{Cu}_{2}$
(751.66). Calc'd: C 38.34; H 4.26; N $14.91 \%$. Found: C 38.20; H 4.22; N $14.85 \%$.

\section{RESULTS AND DISCUSSION}

\section{Synthesis}

The complex was obtained by the reaction of copper(II) acetate monohydrate, $\mathrm{Cu}(\mathrm{Ac})_{2} \cdot \mathrm{H}_{2} \mathrm{O}$, and caffeine $\left(\mathrm{C}_{8} \mathrm{H}_{10} \mathrm{~N}_{4} \mathrm{O}_{2}\right)$ in a $1: 1$ molar ratio both by the solution-based method in methanol and mechanochemically by the LAG method with methanol or ethanol in a ball mill (Scheme 2). Taking into account the proper formula of the dimeric complex of copper(II) acetate monohydrate, $\left[\mathrm{Cu}_{2}(\mu \text {-Ac })_{4}\left(\mathrm{H}_{2} \mathrm{O}\right)_{2}\right]$, the ratio to caffeine is $1: 2$. It was found that the exchange of the two coordinated $\mathrm{H}_{2} \mathrm{O}$ molecules with caffeine molecules occurs only by the assistance of methanol or ethanol.

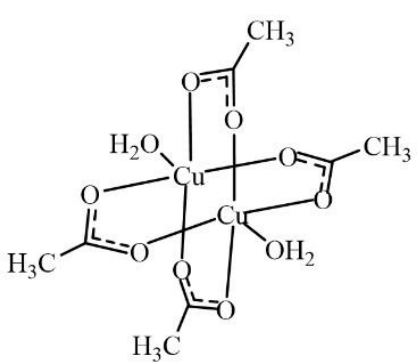<smiles>Cn1c(=O)c2c(ncn2C)n(C)c1=O</smiles>

LAG (MeOH, EtOH)

Reflux (MeOH, EtOH)

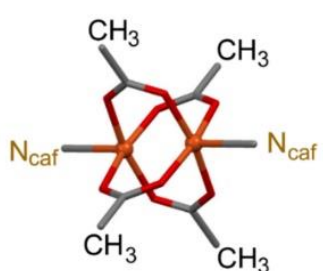

Scheme 2. Synthesis of $\left[\mathrm{Cu}_{2}(\mu-\mathrm{Ac})_{4}(\mathrm{caf})_{2}\right]$

Several other mechanochemical procedures were tried and the reaction products were monitored by PXRD. Neat grinding (NG) and LAG of copper(II) acetate monohydrate (Figure 3a) and caffeine (Figure $3 \mathrm{~b}$ ) in the 1:1 ratio with added water ground with a mortar and pestle were performed for $15 \mathrm{~min}$. Such short grinding with or without addition of water resulted only in the mixture of copper(II) acetate and caffeine (Figure 3c). The same procedure was tried with LAG (methanol) but such short grinding with no compensation done for evaporation of methanol resulted in the same mixture. To obtain the complex with caffeine this mixture had to be soaked with methanol or ethanol to form a slurry (Figure 3g). PXRD pattern of the product of LAG for 1 hour in a ball mill with added water showed presence of copper(II) acetate monohydrate, however the highest caffeine peak almost disappeared and two new low angle peaks formed that could not be assigned, but there were no peaks of the caffeine complex (Figure 3d). On contrary, LAG with meth- anol or ethanol in a ball mill for 1 hour resulted in the caffeine complex $\left[\mathrm{Cu}_{2}(\mu-\mathrm{Ac})_{4}(\mathrm{caf})_{2}\right]$ (Figure $3 \mathrm{~h}$ ). The same complex was obtained by the solutionbased method which gave single-crystals suitable for the crystal structure determination (Figure 3i).

Tella et al. [34] have recently published a synthesis of $\left[\mathrm{Cu}(\mathrm{caf})_{2}\left(\mathrm{H}_{2} \mathrm{O}\right)(\mathrm{Ac})\right] \mathrm{Ac}$ by both mechanochemical and solution-based methods, however the molar ratio of $\mathrm{Cu}(\mathrm{Ac})_{2} \cdot \mathrm{H}_{2} \mathrm{O}$ and caffeine was $1: 2$ $\left(\left[\mathrm{Cu}_{2}(\mu-\mathrm{Ac})_{4}\left(\mathrm{H}_{2} \mathrm{O}\right)_{2}\right]\right.$ :caffeine $\left.=1: 4\right)$. Therefore, during this synthesis the dinuclear paddle-wheel unit would be broken and a mononuclear complex obtained. The authors have characterized this complex by elemental analysis, FT-IR, UV-Vis and $1 \mathrm{H}$ NMR spectra but not by the single-crystal X-ray diffraction. The proposed structure consists of copper atom coordinated with two bidentately donating caffeine ligands through the nitrogen atom of the imidazole group and the oxygen atom of the pyrimidine group, a water molecule and an acetate ligand. One acetate is proposed to be a free anion. A caf- 
feine molecule to be bidentately coordinating one copper atom we consider highly unlikely. In our opinion only a polymeric structure would be possible. We followed their synthetic procedure $(1 \mathrm{mmol}$ of copper(II) acetate and $2 \mathrm{mmol}$ of caffeine were ground together with a mortar and pestle for $15 \mathrm{~min}$; a bluish-green powder was washed with methanol) and collected the PXRD pattern of the product before washing with methanol and obtained only a mixture of copper(II) acetate monohydrate and caffeine, with more caffeine than in our 1:1 synthesis (Figure 3e). Upon washing with a small amount of methanol the same caffeine complex is formed as in our synthesis but there is an excess of unreacted caffeine (Figure 3f). There are no peaks that correspond to their powder pattern. It has to be noted that they have made an error and instead of a powder pattern of copper(II) acetate monohydrate they gave a pattern of copper(II) chloride dihydrate.

Contrary to Tella et al., the same complex as ours was obtained by a solution-based method in ethanol (reflux for 4 hours) by Hamdani et al. [35]. The ratio of copper(II) acetate monohydrate and caffeine was $1: 2$, and not $1: 1$ as in our synthesis.

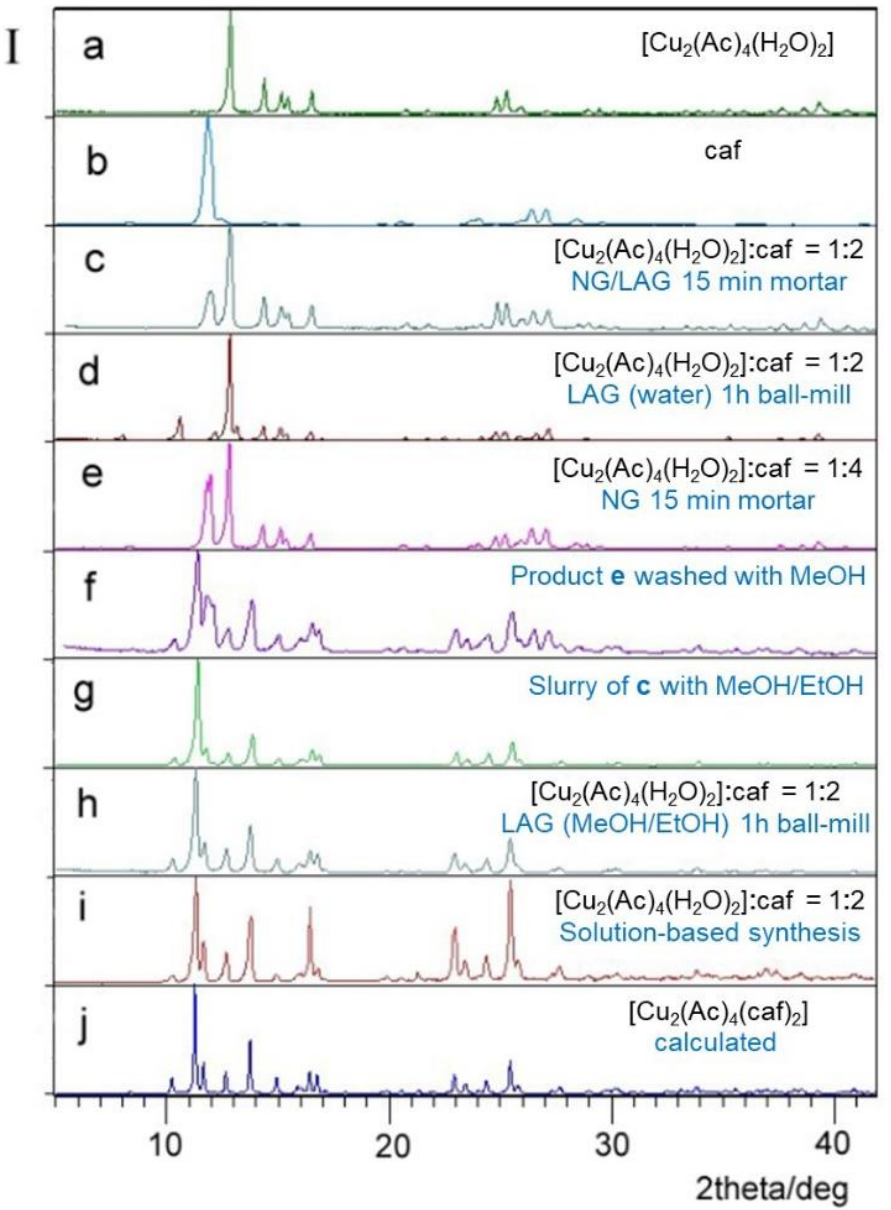

Figure 3. Powder diffractograms of: (a) copper(II) acetate monohydrate $\left(\mathrm{Cu}(\mathrm{Ac})_{2} \cdot \mathrm{H}_{2} \mathrm{O}=\left[\mathrm{Cu}_{2}(\mu-\mathrm{Ac})_{4}\left(\mathrm{H}_{2} \mathrm{O}\right)_{2}\right]\right)$;

(b) caffeine; (c) product of NG or LAG (water) for 15 min by hand; (d) product of LAG (water) for 1 hour in a ball-mill;

(e) product of NG for 15 min by hand (procedure by Tella et al.); (f) product (e) washed with $\mathrm{MeOH}$; (g) product

(c) with added $\mathrm{MeOH}$ or EtOH to form a slurry; (h) product of LAG (MeOH or EtOH) for 1 hour in a ball mill;

(i) solution-based synthesis; (j) calculated powder pattern from the crystal structure of $\left[\mathrm{Cu}_{2}(\mu \text {-Ac })_{4}(\mathrm{caf})_{2}\right]$.

\section{FT-IR spectroscopy}

Table 3 presents the most important IR spectral bands for caffeine, copper(II) acetate monohydrate and $\left[\mathrm{Cu}_{2}(\mu-\mathrm{Ac})_{4}(\mathrm{caf})_{2}\right]$ obtained via the solution-based and mechanochemical methods. The carboxylate stretching frequencies $1\left(-\mathrm{COO}^{-}\right)_{\text {asym }}$ at $1620 \mathrm{~cm}^{-1}$ and $v\left(-\mathrm{COO}^{-}\right)_{\text {sym }}$ at $1426 \mathrm{~cm}^{-1}$ are characteristic for copper(II) carboxylate compounds [15, 36, 37] (Figure 4). The two strong band at 1700 $\mathrm{cm}^{-1}$ and $1660 \mathrm{~cm}^{-1}$ were attributed to $v(\mathrm{CO})_{\text {asym }}$ and $v(\mathrm{CO})_{\text {sym }} / v(-\mathrm{C}=\mathrm{N})$ in free caffeine, the latter 
shifted to $1650 \mathrm{~cm}^{-1}$ in the copper complex. The $\delta(\mathrm{HCN})+v_{\text {ring }}($ imid $)+v_{\text {ring }}($ pyrim $)$ stretching and deformation of the heterocyclic imidazol and pyrimidine fragments was found at $1550 \mathrm{~cm}^{-1}[38,39]$. This band shifted to $1541 \mathrm{~cm}^{-1}$ in the complex indi- cating that the $(\mathrm{C}=\mathrm{N})$ imidazole fragment of caffeine is involved in coordination with the metal ion through the N9 nitrogen atom. Hamdani et al. obtained the same IR spectrum as ours indicating that they also prepared $\left[\mathrm{Cu}_{2}(\mu-\mathrm{Ac})_{4}(\mathrm{caf})_{2}\right]$.

Table 3. Characteristic IR bands $\left(\mathrm{cm}^{-1}\right)$ in caffeine, copper(II) acetate monohydrate and $\left[\mathrm{Cu}_{2}(\mu \text {-Ac })_{4}(\mathrm{caf})_{2}\right]$

\begin{tabular}{cccc}
\hline Caffeine & $\begin{array}{c}\text { Copper(II)acetate } \\
\text { monohydrate }\end{array}$ & {$\left[\mathbf{C u}_{2}(\boldsymbol{\mu} \text {-Ac })_{4}(\mathbf{c a f})_{2}\right]$} & Attribution \\
\hline 1700 & & 1700 & $v(-\mathrm{C}=\mathrm{O})_{\text {asym }}$ \\
\hline 1660 & & 1650 & $v(-\mathrm{C}=\mathrm{O})_{\text {sym }} / v(-\mathrm{C}=\mathrm{N})$ \\
\hline 1550 & 1541 & $\delta(\mathrm{HCN})+v_{\text {ring }}($ imid $)+v_{\text {ring }}($ pyrim $)$ \\
\hline & 1510 & 1620 & $v\left(-\mathrm{COO}^{-}\right)_{\text {asym }}$ \\
\hline & 1435 & 1426 & $v\left(-\mathrm{COO}^{-}\right)_{\text {sym }}$ \\
\hline
\end{tabular}

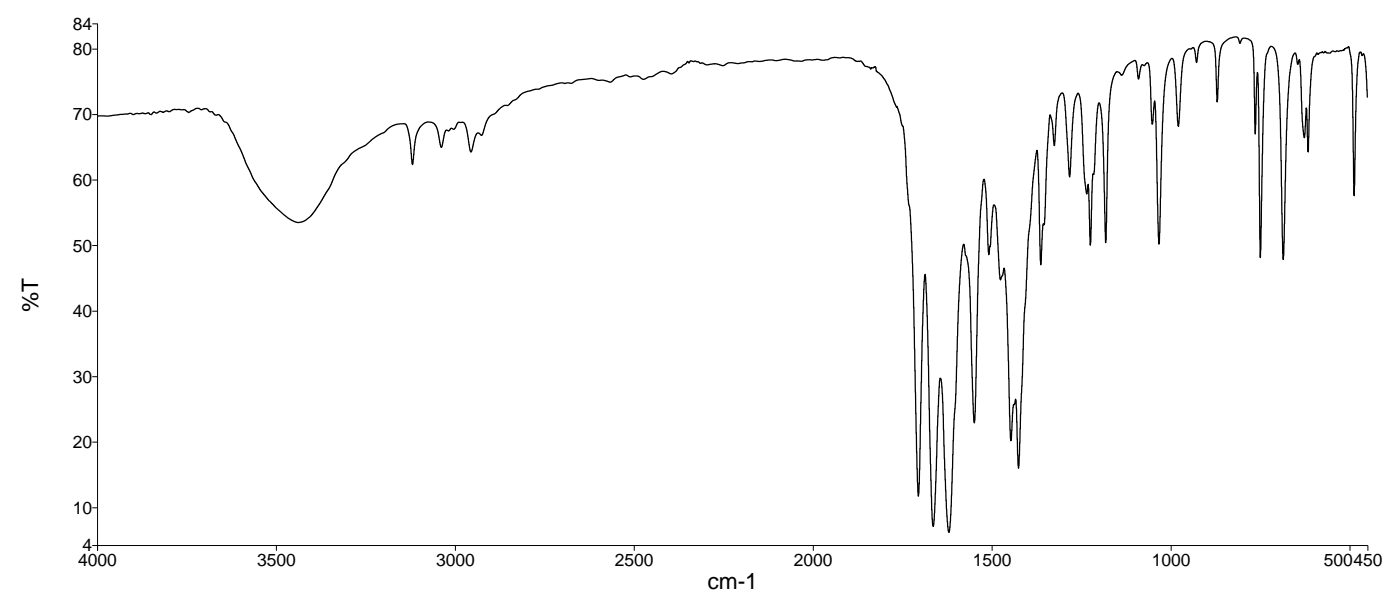

Figure 4. Infrared spectra of $\left[\mathrm{Cu}_{2}(\mu-\mathrm{Ac})_{4}(\mathrm{caf})_{2}\right]$ obtained via the solution-based or mechanochemical method (LAG, MeOH)

Thermal analysis

Complex $\left[\mathrm{Cu}_{2}(\mu-\mathrm{Ac})_{4}(\mathrm{caf})_{2}\right]$ was heated from room temperature to $600{ }^{\circ} \mathrm{C}$ (TG) and from room temperature to $500{ }^{\circ} \mathrm{C}$ (DSC) in an oxygen atmosphere. The TG curve of the complex shows two degradation steps. The first step between 234 and 272 ${ }^{\circ} \mathrm{C}$ is accompanied by a $32.3 \%$ weight loss (calculated $31.4 \%$ ) corresponding to the elimination of the acetato ligands. This step is represented by two exothermic peaks at 255 and $287^{\circ} \mathrm{C}$ on the DSC curve. Three exothermic peaks with maxima at 363 , 368 and $375{ }^{\circ} \mathrm{C}$ are associated with the elimination of two caffeine molecules (observed weight loss $45.1 \%$, calculated $51.6 \%$ ). The remaining residue of $21.5 \%$ at $600{ }^{\circ} \mathrm{C}$ is $\mathrm{CuO}$.

\section{X-ray crystal structure}

The X-ray structure of $\left[\mathrm{Cu}_{2}(\mu-\mathrm{Ac})_{4}(\mathrm{caf})_{2}\right]$ is depicted in Figure 5. The complex molecule contains the dinuclear paddle-wheel unit with two copper atoms and four bridging acetate ligands. It is centrosymmetric with the center of inversion located between the two copper atoms so there is a half of the molecule in the asymmetric unit. Each of the copper(II) atoms is coordinated by four acetato groups as equatorial ligands and one nitrogen atom from the caffeine ligand, localised at the apex of a distorted square pyramid. 


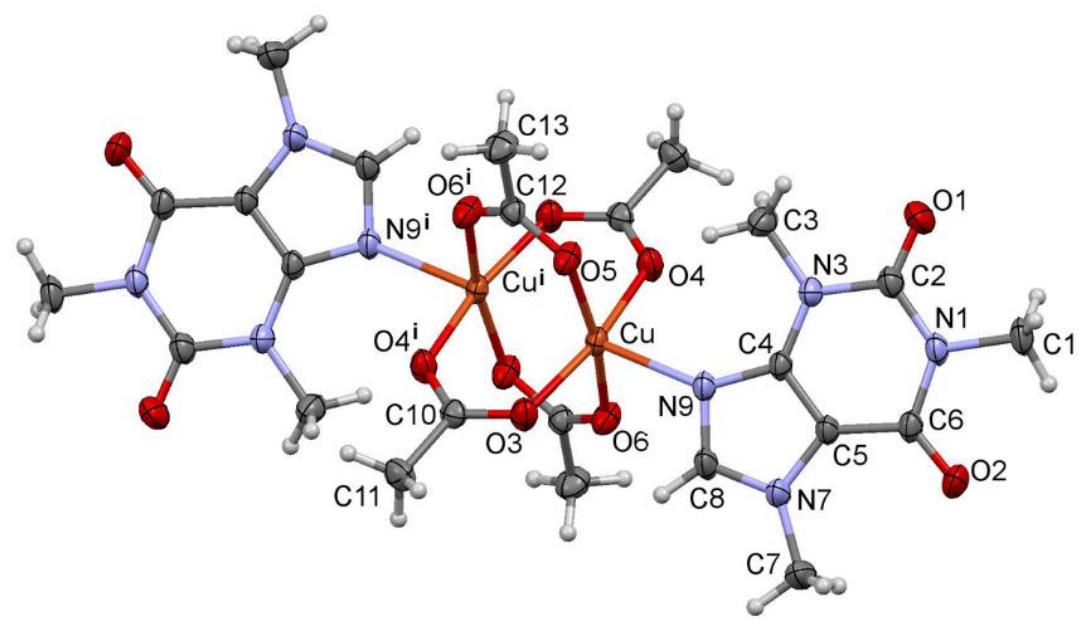

Fig. 5. Molecular structure of $\left[\mathrm{Cu}_{2}(\mu-\mathrm{Ac})_{4}(\mathrm{caf})_{2}\right]$ with the atom labeling scheme. Symmetry code: $i=1-x, 1-y,-z$. The ellipsoids are at the $40 \%$ probability level. Hydrogen atoms are depicted as spheres of arbitrary radii.

The $\mathrm{Cu} \cdots \mathrm{Cu}$ distance of 2.6350(3) $\AA$ is the shortest one among the known dinuclear $\left[\mathrm{Cu}_{2}(\mathrm{RCOO})_{4}(\mathrm{caf})_{2}\right]$ complexes (Table 1). The displacement of the $\mathrm{Cu}$ atom from the equatorial plane (atoms O3-06) toward the apical atom of $\mathrm{N}(9)$ amounts to $0.202(1) \AA$. The apical $\mathrm{Cu}-\mathrm{N}$ (caf) bond length is $2.2585(10) \AA$ being the longest one in comparison to other complexes (Table 1). Each $\mathrm{Cu}$ (II) ion has four oxygen atoms from different carboxylate groups in the equatorial positions, with $\mathrm{Cu}-\mathrm{O}$ distances in the range from $1.9689(10)$ to 1.9716(10) $\AA$, Table 4. These values are comparable to those found in other $\mathrm{Cu}(\mathrm{II})$ carboxylates.

The geometry of the caffeine ligand linked to the metal center indicates delocalization of $\pi$ - electrons

Table 4. Selected bond distances $(\AA)$ and valence angles $\left(^{\circ}\right)$ for $\left[\mathrm{Cu}_{2}(\mu-\mathrm{Ac})_{4}(\mathrm{caf})_{2}\right]$

\begin{tabular}{lr}
\hline Bond distances & \\
\hline $\mathrm{Cu}-\mathrm{O} 3$ & $1.9716(10)$ \\
$\mathrm{Cu}-\mathrm{O} 4$ & $1.9554(10)$ \\
$\mathrm{Cu}-\mathrm{O} 5$ & $1.9624(10)$ \\
$\mathrm{Cu}-\mathrm{O} 6$ & $2.2585(10)$ \\
$\mathrm{Cu}-\mathrm{N} 9$ & \\
Bond angles & $168.02(4)$ \\
O3-Cu-O4 & $90.96(5)$ \\
$\mathrm{O} 3-\mathrm{Cu}-\mathrm{O} 5$ & $87.43(5)$ \\
$\mathrm{O} 3-\mathrm{Cu}-\mathrm{O} 6$ & $168.31(4)$ \\
$\mathrm{O} 5-\mathrm{Cu}-\mathrm{O} 6$ & $95.24(4)$ \\
$\mathrm{O} 3-\mathrm{Cu}-\mathrm{N} 9$ & $96.51(4)$ \\
$\mathrm{O} 4-\mathrm{Cu}-\mathrm{N} 9$ & $99.38(4)$ \\
$\mathrm{O} 5-\mathrm{Cu}-\mathrm{N} 9$ & $92.30(4)$ \\
$\mathrm{O} 6-\mathrm{Cu}-\mathrm{N} 9$ & \\
\hline
\end{tabular}

within the pyrimidine and imidazole ring of caffeine. Both rings are planar with a maximum deviation of N9 amounting to 0.025(1) $\AA$ from the leastsquares plane through the ring atoms. Maximum ring substituent deviation from this plane is that of C(3) being 0.066(2) A.

The complex structure is stabilized by weak $\mathrm{C} 3-\mathrm{H} \cdots \mathrm{O} 5$ intramolecular hydrogen bond. There are also only weak intermolecular hydrogen bonds of the $\mathrm{C}-\mathrm{H} \cdots \mathrm{O}$ type interconnecting the complex molecules in a 3D structure since C-H groups are the only available hydrogen bond donors. The relevant characteristics of $\mathrm{H}$-bonds are given in Table 5 and the packing is shown in Figure 6.

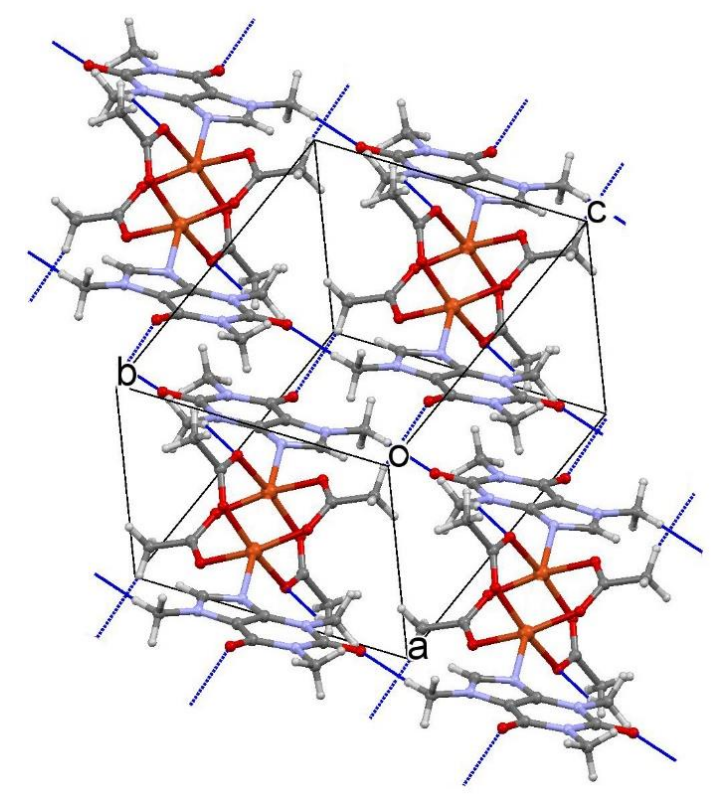

Figure 6. Packing diagram of $\left[\mathrm{Cu}_{2}(\mu \text {-Ac })_{4}(\mathrm{caf})_{2}\right]$ in the unit cell. Hydrogen bonds are shown by blue dotted lines. 
Table 5. Hydrogen bonding parameters

\begin{tabular}{lccccc}
\hline & \multicolumn{3}{c}{ Distance $/ \AA$} & Angle ${ }^{\circ}$ & Symmetry code \\
$\mathrm{D}-\mathrm{H} \cdots \mathrm{A}$ & $\mathrm{D}-\mathrm{H}$ & $\mathrm{H} \cdots \mathrm{A}$ & $\mathrm{D} \cdots \mathrm{A}$ & $\mathrm{D}-\mathrm{H} \cdots \mathrm{A}$ & \\
\hline $\mathrm{C} 3-\mathrm{H} \cdots \mathrm{O} 5$ & 0.96 & 2.49 & $3.4028(19)$ & 159 & \\
$\mathrm{C} 7-\mathrm{H} \cdots \mathrm{O} 1$ & 0.96 & 2.28 & $3.232(2)$ & 172 & $x,-1+y, z$ \\
$\mathrm{C} 11-\mathrm{H} \cdots \mathrm{O} 2$ & 0.96 & 2.53 & $3.451(2)$ & 161 & $1-x, 1-y, 1-z$ \\
\hline
\end{tabular}

\section{CONCLUSION}

By direct reaction of copper(II) acetate monohydrate with caffeine in the 1:1 molar ratio, either by the solution-based method or mechanochemically (LAG with methanol or ethanol) the dinuclear complex, $\left[\mathrm{Cu}_{2}(\mu \text {-Ac })_{4}(\mathrm{caf})_{2}\right]$, was prepared. It was found that the addition of methanol or ethanol is necessary for the formation of the complex since NG or LAG with water did not result in the complex formation. We have found that the replacement of water molecules by caffeine molecules in the paddle-wheel copper(II) acetate complex proceeds also in a slurry at room temperature only by the addition of a few drops of methanol or ethanol to the homogenized mixture of the reactants (with a mortar and pestle for $15 \mathrm{~min}$ ). This is the fastest and easiest way to prepare the complex. The obtained complex consists of the paddle-wheel dimeric $\mathrm{Cu}_{2}\left(\mathrm{O}_{2} \mathrm{CCH}_{3}\right)_{4}$ unit with $\mathrm{N}$-coordinated caffeine molecules in both apical positions. Each copper(II) atom is five coordinated (distorted square-pyramidal) with four oxygen atoms from four acetato anions in the equatorial positions and the caffeine $\mathrm{N}$ atom in the apical position $(\mathrm{Cu}-\mathrm{N}$ 2.2585(10) $\AA$ ). The $\mathrm{Cu} \cdots \mathrm{Cu}$ distance is 2.6350(3) $\AA$. The copper(II) atoms are displaced from the O4 equatorial plane by $0.202(1) \AA$ toward the apical $\mathrm{N}$-atom of caffeine.

Acknowledgment. We thank the Croatian Science Foundation for funding the project IP-2014-09-4274.

\section{REFERENCES}

[1] M. Melnik, O. Sprusansky, P. Musil, Bio-medical aspects of purine alkaloids, Adv. Biol. Chem., 4 (2014), pp. 274-280.

[2] S. V. Paston, A. M. Polyanichko, O. V. Shulenina, Study of DNA interactions with $\mathrm{Cu}^{2+}$ and $\mathrm{Mg}^{2+}$ ions in the presence of caffeine, J. Struct. Chem., 58 (2017), pp. 399-405.

[3] M. B. Cingi, A. Ch. Villa, A. G. Manfredotti, C. Guastini, Crystal structure of triaquanitratocaf-
feinecopper(II) nitrite monohydrate, Cryst. Struct. Commun., 1 (1972), pp. 363-365.

[4] G. Bandoli, M. B. Cingi, D. A. Rizzardi, Preparation, crystal and molecular structure of aquadichlorocaffeinecopper(II), Inorg. Chim. Acta, 20 (1976), pp.71-76.

[5] T. Kawata, H. Uekusa, S. Ohba, T. Furukawa, T. Tokii, Y. Muto, M. Kato, Magneto-structural correlation in dimeric copper(II) benzoates, Acta Cryst., B48 (1992), pp. 253-261.

[6] M. Koman, M. Melnik, J. Moncol', T. Glowiak, Caffeine in copper(II) complexes: crystal and molecular structure of di(caffeine)tetrakis(naproxenato)dicopper(II), Inorg. Chem. Commun., 3 (2000), pp. 489-492.

[7] F. Valach, M. Tokarčik, M. Melnik, Distortion isomerism and plasticity of the coordination sphere of binuclear $\mathrm{Cu}(\mathrm{II})$ complexes: Crystal structure of the monoclinic isomer of $\left[\mathrm{Cu}_{2}\right.$ (2-bromopropionato $)_{4}$ (caffeine $)_{2}$, Journal of Coord. Chem. 62 (2009), pp. 225-233.

[8] Z. Ma, B. Moulton, Supramolecular medicinal chemistry: mixed-ligand coordination complexes, Mol. Pharmaceutics, 4 (2007), pp. 373-385.

[9] F. Valach, M. Melnik, G. Bernardinelli, K. K. Fromm, A structural study of copper(II) carboxylates: crystal structure and physical characterization of $\left[\mathrm{Cu}_{2} \text { (2-bromo-propionato }\right)_{4}$ (caffeine) $\left.)_{2}\right], J$. Chem. Crystallogr., 36 (2006), pp. 571-579.

[10] F. Valach, M. Tokarčik, T. Maris, D. J. Watkin, C. K. Prout, Bond-valence approach to the coppercopper and copper-nitrogen bonding in binuclear copper(II) complexes: Structure of tetrakis(2iodobenzoato)bis(caffeine)dicopper(II) at $210 \mathrm{~K}, J$. Organomet. Chem., 622 (2001), pp. 166-171.

[11] B. Koreň, F. Valach, P. Sivý, M. Melnik, Structures of binuclear copper(II) chloroacetate complexes: tetrakis $(\mu$-monochloroacetato- $O, O$ )-bis[3,7-dihydro-1,3,7-trimethyl-1 $H$-purine-2,6-dione)copper(II)], $\left[\mathrm{Cu}_{2}\left(\mathrm{C}_{2} \mathrm{H}_{2} \mathrm{ClO}_{2}\right) 4\left(\mathrm{C}_{8} \mathrm{H}_{10} \mathrm{~N}_{4} \mathrm{O}_{2}\right)_{2}\right]$, Acta Cryst., C41 (1985), pp. 1160-1162.

[12] A. Harada, M. Tsuchimoto, S. Ohba, K. Iwasawa, T. Tokii, Structures and magnetic properties of dimeric copper(II) benzoylformates, Acta Cryst., B53 (1997), pp. 654-661. 
[13] H. Horie, S. Husebye, M. Kato, E. A. Meyers, Y. Muto, I. Suzuki, T. Tokii, R. A. Zingaro, The magnetic properties of three copper(II) trichloroacetate; Adducts with caffeine and the crystal structure of dicaffeinetetrakis $(\mu$-trichloroacetato)dicopper(II)dibenzene solvate, $\left[\mathrm{Cu}\left(\mathrm{CCl}_{3} \mathrm{COO}\right)_{2}\left(\mathrm{C}_{8} \mathrm{H}_{10} \mathrm{~N}_{4} \mathrm{O}_{2}\right)_{2}\right]_{2}$. $2 \mathrm{C}_{6} \mathrm{H}_{6}$, Acta. Chem. Scand. A, 40 (1986), pp. 579589.

[14] H. Uekusa, S. Ohba, T. Tokii, Y. Muto, M. Kato, S. Husebye, O.W. Steward, S.-C. Chang, J. P. Rose, F. Pletcher, I. Suzuki, Magneto-structural correlations of dimeric copper(II) trichloroacetates, Acta Cryst., B48 (1992), pp. 650-667.

[15] M. Melnik, M. Koman, T Glowiak, Structure, spectral and magnetic behaviours of tetrakis(flufenamato)(caffeine)(aqua)dicopper(II). The firs example of two nonequivalent ligands at the apex, Polyhedron, 17 (1998), pp.1767-1771.

[16] P. Stachová, J. Moncol, D. Valigura, T. Lis, Unusual $O$-coordination of caffeine in tetrakis $(\mu-3,5$ dinitrobenzoato- $\kappa^{2} O: O$ )bis[(caffeine- $\left.\kappa O\right)$ copper(II)], Acta Cryst., C62 (2006), pp. m375-m377.

[17] C. R. Groom, I. J. Bruno, M. P. Lightfoot and S. C. Ward, Acta Cryst., B72 (2016), pp. 171-179.

[18] T. Friščić, I. Halasz, V.Štrukil, M. Eckert-Maksić, R. E. Dinnebier, Clean and efficient synthesis using mechanochemistry: coordination polymers, metalorganic frameworks and metallodrugs, Croat. Chem. Acta, 85(3) (2012), pp. 367-378.

[19] F. C. Strobridge, N. Judaš, T. Friščić, A stepwise mechanism and the role of water in the liquidassisted grinding synthesis of metal-organic materials, CrystEngComm 12 (2010), pp. 2409-2418.

[20] A. Pichon, S. L. James, An array-based study of reactivity under solvent-free mechanochemical conditions - insights and trends, CrystEngComm, 10 (2008) pp. 1839-1847.

[21] W. Yuan, A. L. Garay, A. Pichon, R. Clowes, C. D. Wood, A. I. Cooper, S. L. James, Study of mechanochemical formation and resulting properties of an archetypal MOF: $\mathrm{Cu}_{3}(\mathrm{BTC})_{2}(\mathrm{BTC}=1,3,5$-benzenetricarboxylate), CrystEngComm, 12 (2010) pp. 4063-4065.

[22] J. Pejić, D. Vušak, G. Szalontai, B. Prugovečki, D. Mrvoš-Sermek, D. Matković-Čalogović, J. Sabolović, Disorder at the chiral $\mathrm{C} \alpha$ center and roomtemperature solid-state cis-trans isomerization; synthesis and structural characterization of copper(II) complexes with D-allo, L-isoleucine, Cryst. Growth Des., 18 (2018), pp. 5138-5154.

[23] D. Vušak, B. Prugovečki, D. Milić, M. Marković, I. Petković, M. Kralj, D. Matković-Čalogović, Synthesis and crystal structure of solvated complexes of copper(II) with serine and phenanthroline and their solid-state-to-solid-state transformation into one stable solvate. Cryst. Growth Des. 17 (2017), pp. 6049-6061.
[24] STARe Software V.9.01., MettlerToledo GmbH, (2006).

[25] CrysAlisPro Software System, Version 1.171.39.19; Rigaku Oxford Diffraction (2017).

[26] L. J. Farrugia, J. Appl. Crystallogr., 45 (2012), pp. 849-854.

[27] G. M. Sheldrick, A short history of SHELX, Acta Cryst., A64 (2008), pp. 112-122.

[28] G. M. Sheldrick, Crystal structure refinement with SHELXL, Acta Cryst., C71 (2015), pp. 148-155.

[29] A. Spek, Structure validation in chemical crystallography, Acta Cryst., D65 (2009), pp. 148-155.

[30] C. F. Macrae, I. J. Bruno, J. A. Chisholm, P. R. Edgington, P. McCabe, E. Pidcock, L. RodriguezMonge, R. Taylor, J. van de Streek, P. A. Wood, Mercury CSD 2.0 - new features for the visualization and investigation of crystal structures, J. Appl. Crystallogr., 41 (2008), pp. 466-470.

[31] L. J. Farrugia, ORTEP-3 for Windows - a version of ORTEP-III with a Graphical User Interface (GUI), $J$. Appl. Crystallogr., 30 (1997) pp. 565-566.

[32] POV-Ray, version 3.6; Persistence of Vision Pty. Ltd., Persistence of Vision Raytracer, (2004), available at http://www.povray.org/.

[33] T. Degen, M. Sadki, E. Bron, U. König, G. Nénert, Powder Diffraction, Supplement S2, 29 (2014), pp. S13-S18.

[34] A. C. Tella, J. A. Obaleye, U. B. Eke, A. Y. Isaac, O. M. Ameen, Solvent-free synthesis, X-ray studies and in vitro inhibitory activities of copper(II) complexes of non-steroidal anti-inflammatory drugs, Res. Chem. Intermed, 40 (2014), pp. 1441-1457.

[35] H. EL Hamdani, M. EL. Amane, Y. Kennouche, M. Bouhdada, A. Ahmami, M. Hadad, Synthesis and characterization of the mixed ligand complexes $\left[\mathrm{M}(\mathrm{Ac})_{2}(\mathrm{caf})_{2}\right] \mathrm{M}=\mathrm{Ni}(\mathrm{II}), \mathrm{Co}(\mathrm{II}), \mathrm{Zn}(\mathrm{II}), \quad\left[\mathrm{Cu}_{2}(\mu-\right.$ Ac) $\left.)_{4}(\mathrm{caf})_{2}\right], \mathrm{Ac}=\mathrm{CH}_{3} \mathrm{COO}^{-}$, caf $=$caffeine, J. Mar. Chim. Heterocycl., 15 (2016), pp. 41-49.

[36] M. Melnik, Binuclear caffeine adducts of $\mathrm{Cu}(\mathrm{II})$ acetate and $\mathrm{Cu}(\mathrm{II})$ chloroacetates with unusually high antiferromagnetic interaction, Inorg. Nucl. Chem., 43 (1981), pp. 3035-3038.

[37] S. J. Jenniefer, P. T. Muthiah, Synthesis, characterization and X-ray structural studies of four copper(II) complexes containing dinuclear paddle wheel structures, Chem. Cent. J., 7 (2013), pp. 1-15.

[38] K. Nakamoto, Infrared Spectra of Inorganic and Coordination Compounds, J. Wiley \& Sons., Inc. New York, 2009.

[39] F. Ucun, A. Sağlam, V. Güçlü, Molecular structures and vibrational frequencies of xanthine and methyl derivatives (caffeine and theobromine) by abinitio Hartree-Fock and density functional theory calculations, Spectrochim. Acta Part A, 67 (2007), pp. 342-349. 


\section{БИНУКЛЕАРЕН БАКАРЕН(ІІ) АЦЕТАТЕН КОМПЛЕКС СО КОФЕИН, БРЗА МЕХАНОХЕМИСКА СИНТЕЗА}

\section{Marina Tašner, Draginja Mrvoš-Sermek*, Emina Hajdarpašić, Dubravka Matković-Čalogović}

Department of Chemistry, Faculty of Science, University of Zagreb,

Horvatovac 102a, 10000 Zagreb, Croatia

e-mail:

Синтетизиран е нов бинуклеарен пропелерски тип (paddle-wheel) на бакарен(II) комплекс со кофеин со помош на механохемиски метод заснован на растворувач, а поаѓајќ́ од бакар(II) ацетат и кофеин во моларен сооднос 1:1. Најдено е дека механохемиската синтеза е најбрз и најлесен начин за подготвка на комплексот. Реакцијата се одвива со додавање на мало количество метанол или етанол. Комплексот е карактеризиран со помош на FT-IR спектроскопија, анализа на хемиските елементи, термоаналитички методи (TG and DSC) и метод на рендгенска дифракција. Молекулската и кристалнта структура се определени со помош на рендгенска дифракција од монокристал. Комплексната молекула се состои од центросиметрична бинуклеарна единка од типот $\left[\mathrm{Cu}_{2}(\mu \text {-Ac })_{4}(\mathrm{caf})_{2}\right]$, што ја чинат два бакарни(II) атома премостени преку четири ацетатни групи, како и $N$ координирани кофеински (caf) молекули во апикални положби.

Клучни зборови: бакар(II); пропелерска (paddle-wheel) структура; кофеин; кристална структура; механохемиска синтеза 
